\title{
An in-vivo method for estimating inhibin production by adult rat testes*
}

\author{
C. L. Au†, D. M. Robertson and D. M. de Kretser \\ Department of Anatomy, Monash University, Clayton, Victoria 3168, Australia
}

\begin{abstract}
Summary. The concentrations of inhibin in samples of rat testicular venous and arterial blood and interstitial fiuid were measured by an in-vitro bioassay using pituitary cells in culture in which the standard was an ovine testicular lymph preparation (assigned potency $1 \mathrm{unit} / \mathrm{mg})$. Inhibin levels were undetectable $(<2 \mathrm{U} / \mathrm{ml})$ in both blood samples but reached a mean concentration of $120 \pm 7 \mathrm{U} / \mathrm{ml}$ in testicular interstitial fluid. After unilateral efferent duct ligation the rate of inhibin accumulation in seminiferous tubules was determined by the difference in the inhibin content of the ligated and unligated testes. Additionally, the rate of seminiferous tubule fluid production was obtained from the difference in weight between the ligated and non-ligated testes. In the $24 \mathrm{~h}$ after efferent duct ligation there were linear increases in inhibin $(18.5 \pm 1.0$ $\mathrm{U} / \mathrm{h})$ and in seminiferous tubule fluid production $(26 \pm 1 \mu \mathrm{l} / \mathrm{h})$, but there were no changes in serum FSH and LH levels.

Experimental induction of bilateral cryptorchidism led to a decrease in the inhibin content of the testis after 10 days. The rate of inhibin accumulation after efferent duct ligation declined more rapidly than the inhibin content, being significantly depressed in cryptorchid testes after 3 days, suggesting that this measurement is a more sensitive index of inhibin production than the determination of testicular inhibin content.
\end{abstract}

\section{Introduction}

We have demonstrated that the inhibin content of the rat testis can be determined by using testicular extracts in an in-vitro bioassay which uses pituitary cells in culture (Au, Robertson \& de Kretser, 1983). However, little is known of the distribution of inhibin in the various compartments of the testis or in its venous or lymphatic drainage. Based on the evidence that inhibin is produced by the Sertoli cell (Steinberger \& Steinberger, 1976; Le Gac \& de Kretser, 1982), and is present in rete testis fluid (Setchell \& Sirinathsinghji, 1972; Baker et al., 1976; Blanc \& Dacheux, 1976), we have examined the possibility of using the accumulation of inhibin in seminiferous tubules after unilateral efferent duct ligation as an index for measuring the rate of testicular inhibin production in vivo. This technique has been applied to obtain an assessment of the production rate of another Sertoli cell product, androgen-binding protein (ABP), in rat testes (Hägenas \& Ritzén, 1976; Jégou, Laws \& de Kretser, 1982a). The possibility that the accumulation of inhibin after efferent duct ligation represents a more sensitive index of inhibin production than the simple measurement of the testicular inhibin content was explored in rats in which cryptorchidism was experimentally induced.

* Reprint requests to Dr D. M. de Kretser.

† Present address: Department of Physiology, Chinese University of Hong Kong, Shatin, N.T. Hong Kong. 


\section{Materials and Methods}

\section{Surgical procedures}

Efferent duct ligation. Unilateral ligation of the efferent ducts was performed on a group of adult Sprague-Dawley rats (80 days of age) according to the technique of Smith (1962). Under light ether anaesthesia, ligation was performed via a scrotal incision on alternate sides in each successive animal. At intervals of $6,12,16,20$ and $24 \mathrm{~h}$ after surgery, 7 animals were killed by decapitation. The inhibin contents of ligated and non-ligated testes were determined separately and the difference between the levels was taken as the inhibin production index. Seminiferous tubule fluid production was measured as the difference in weight between the ligated and non-ligated testes (Jégou, Le Gac \& de Kretser, 1982b). These indices can only be taken to represent a relative production rate of fluid and inhibin because the fluid and inhibin probably undergo some degree of resorption across the basement membrane of the seminiferous tubule.

Cryptorchidism. In our previous studies of cryptorchid rats we noted that at 3 days after treatment a significant increase in serum FSH concentrations occurred despite a normal testicular inhibin content (Au et al., 1983). The present study was therefore designed to determine whether the accumulation of inhibin after unilateral efferent duct ligation could be used to detect changes in the production rate before any decline in the inhibin content of cryptorchid testes. Groups of adult rats were sham-operated or made bilaterally cryptorchid as previously described (de Kretser, Sharpe \& Swanston, 1979). At 3, 10 and 25 days after operation, 7 animals from each group were killed by decapitation. Unilateral efferent duct ligation was performed $16 \mathrm{~h}$ before death. Blood was collected from individual animals for the measurement of serum FSH and LH concentrations.

Collection of testicular interstitial fluid and venous blood. Testicular interstitial fluid was obtained following the method of Jégou et al. (1982b). In brief the method consisted of incising the tunica albuginea carefully and allowing the interstitial fluid to collect at $4^{\circ} \mathrm{C}$ for $16 \mathrm{~h}$. The fluid was checked for the presence of spermatozoa, then pooled, centrifuged to remove cellular elements (mainly erythrocytes), and stored at $-20^{\circ} \mathrm{C}$ before inhibin bioassay.

Testicular venous blood was collected from veins on the surface of the testes immediately beneath the capsule. Under anaesthesia a testicular vein was carefully incised with a sharp scalpel blade and care was taken not to damage the seminiferous tubules. The blood drained into a $1.5 \mathrm{ml}$ centrifuge cup (Eppendorf), was allowed to clot at $4^{\circ} \mathrm{C}$ and the serum obtained after centrifugation at $1000 \mathrm{~g}$ for $15 \mathrm{~min}$ was stored at $-20^{\circ} \mathrm{C}$ for inhibin assay. Blood samples for the measurement of serum inhibin were also obtained from testicular arteries using the technique described above and from peripheral blood vessels by decapitation.

\section{Inhibin bioassay}

A culture system for rat pituitary cells (Scott, Burger \& Quigg, 1980) was validated for testicular extracts and used to measure inhibin activity as previously described (Au et al., 1983). The inhibin potency of samples was assessed from the dose-dependent suppression of the FSH cell content parallel to a reference preparation derived from ovine testicular lymph and assigned a potency of $1 \mathrm{U} / \mathrm{mg}$ (Eddie, Baker, Higginson \& Hudson, 1979). Rat testis extracts were prepared by homogenization at $4^{\circ} \mathrm{C}$ in Dulbecco's phosphate buffer $\mathrm{pH} 7.4$ and centrifuged at $100000 \mathrm{~g}$ for $1 \mathrm{~h}$ at $4^{\circ} \mathrm{C}$ and the supernatant was used for inhibin measurements. Rat testicular extracts or testicular interstitial fluid were incubated with equal volumes of $1 \%$ Norit A charcoal (in saline) at $4^{\circ} \mathrm{C}$ for 30 min to remove endogenous steroids before bioassay. Sera were extracted with dextran-coated charcoal (10 mg Norit A charcoal and $1 \mathrm{mg}$ Dextran T-70 per ml serum) at room temperature for 10 min followed by a $30 \mathrm{~min}$ incubation at $4^{\circ} \mathrm{C}$ (Baker et al., 1978). Samples $(100 \mu 1)$ in triplicate at each dose level were assayed at 2-5 dilutions serially prepared in saline $(0 \cdot 154 \mathrm{M}-\mathrm{NaCl})$. In 57 bioassays, the assay sensitivity ranged from 0.042 to $0.330 \mathrm{U} /$ well with a mean \pm s.d. of $0.115 \pm$ $0.051 \mathrm{U} /$ well. The average assay index of precision $(\lambda)$ in 57 assays was 0.102 (range $0.07-0.162$ ). 
The interassay coefficients of variation for the two quality control preparations, a rat testicular extract pool and an ovine rete testis fluid preparation, were respectively $25 \cdot 4 \%$ (20 assays) and $15 \cdot 0 \%$ (10 assays).

\section{Radioimmunoassays for FSH and LH}

FSH and LH concentrations in sera were measured by double antibody radioimmunoassays as previously described (Au et al., 1983) using reagents supplied by the Rat Pituitary Hormone Distribution Program (NIAMDD, MD, U.S.A.). FSH and LH values were expressed in terms of NIAMDD rat FSH-RPI and NIAMDD rat LH-I5 respectively. The assay sensitivities were $75 \mathrm{ng}$ $\mathrm{FSH} / \mathrm{ml}$ and $0 \cdot 1 \mathrm{ng} \mathrm{LH} / \mathrm{ml}$. All serum samples for the one study were run in the same assay and the within-assay coefficient of variation ranged from 4.0 to $9.7 \%$ for both assays.

\section{Statistical analysis}

Values given in the paper represent the mean \pm s.e.m. Parallel-line bioassay statistics were employed in the calculation of inhibition activity (Finney, 1964). Comparisons between groups were made by Student's $t$ test or Duncan's multiple range test (Duncan, 1955).

\section{Results}

Inhibin activity in testicular interstitial fluid and venous plasma

The average inhibin activity was $120 \pm 7 \mathrm{U} / \mathrm{ml}(n=14)$ in pools of testicular interstitial fluid that were free of spermatozoa. Inhibin activity was not detected in blood from the testicular artery or vein or from peripheral vessels, despite using a maximum dose of $100 \mu \mathrm{l}$ serum in the bioassay and, based on the sensitivity of the assay, the inhibin content in the serum samples must be less than $2 \mathrm{U} / \mathrm{ml}$.

\section{Inhibin and seminiferous tubule fluid production}

A significant increase $(P<0.001)$ was observed in the inhibin content of the ligated in comparison to the non-ligated testes in the $24 \mathrm{~h}$ after unilateral efferent duct ligation (Table 1). The

Table 1. Changes in the weight, seminiferous tubule fluid production, inhibin content and inhibin production index of the testis, and serum gonadotrophin levels in rats after unilateral efferent duct ligation

\begin{tabular}{|c|c|c|c|c|c|}
\hline & \multicolumn{5}{|c|}{ Time since efferent duct ligation } \\
\hline & $6 \mathrm{~h}$ & $12 \mathrm{~h}$ & $16 \mathrm{~h}$ & $20 \mathrm{~h}$ & $24 \mathrm{~h}$ \\
\hline \multicolumn{6}{|l|}{ Testis weight $(\mathrm{g})$} \\
\hline Ligated & $1.68 \pm 0.05$ & $1.84 \pm 0.05$ & $1.96 \pm 0.06$ & $2.06 \pm 0.05$ & $2 \cdot 10 \pm 0.08$ \\
\hline Non-ligated & $1.50 \pm 0.05^{*}$ & $1.52 \pm 0.03^{* *}$ & $1.56 \pm 0.05 * *$ & $1.58 \pm 0.04^{* *}$ & $1.54 \pm 0.06^{* *}$ \\
\hline Seminiferous tubule fluid & & & & & \\
\hline production $(\mathrm{g})$ & $0.18 \pm 0.01$ & $0.32 \pm 0.03$ & $0.40 \pm 0.02$ & $0.48 \pm 0.02$ & $0.55 \pm 0.04$ \\
\hline \multicolumn{6}{|c|}{ Testicular inhibin content $(U)$} \\
\hline Ligated & $316 \pm 28$ & $368 \pm 36$ & $483 \pm 23$ & $534 \pm 31$ & $627 \pm 37$ \\
\hline $\begin{array}{l}\text { Non-ligated } \\
\text { Inhibin }\end{array}$ & $188 \pm 11^{* *}$ & $178 \pm 19^{* *}$ & $179 \pm 14^{* *}$ & $170 \pm 15^{* *}$ & $186 \pm 16^{* *}$ \\
\hline $\begin{array}{l}\text { Inniobin production } \\
\text { index }(U)\end{array}$ & $128+20$ & $190+27$ & $304+24$ & $363+24$ & $440+43$ \\
\hline Serum FSH (ng/ml) & $240 \pm 21$ & $201 \pm 21$ & $199 \pm 20$ & $214 \pm 10$ & $183 \pm 14$ \\
\hline Serum LH ( $\mathrm{ng} / \mathrm{ml})$ & $0.70 \pm 0.24$ & $0.31 \pm 0.06$ & $0.57 \pm 0.14$ & $0.57 \pm 0.08$ & $0.47 \pm 0.06$ \\
\hline
\end{tabular}

Values are mean \pm s.e.m. of 7 animals. ${ }^{*} P<0.05,{ }^{* *} P<0.001$ compared to value for ligated testis. 
increase in inhibin content was linear with time. The index of production rate obtained by this ligation procedure was $18.5 \pm 1.0 \mathrm{U} / \mathrm{h}(n=35)$ and was obtained by dividing the inhibin activity in the ligated testes by the time taken for the accumulation to occur. Similarly, the production of seminiferous tubule fluid was linear with time at a rate of $25 \cdot 6 \pm 0.8 \mu \mathrm{l} / \mathrm{h}(n=35)$ (Text-fig. 1). Serum gonadotrophin levels and the inhibin content in the non-ligated testes showed no significant changes at different times after unilateral efferent duct ligation (Table 1). To determine whether an increase in temperature could influence the accumulation of inhibin following efferent duct ligation, in one experiment in which the efferent ducts of rats were bilaterally ligated, the testis on one side was transposed to the abdominal cavity for $16 \mathrm{~h}$. No significant difference was found between the inhibin content of the scrotal $(459 \pm 36 \mathrm{U})$ and the abdominal testes $(427 \pm 37 \mathrm{U})$.

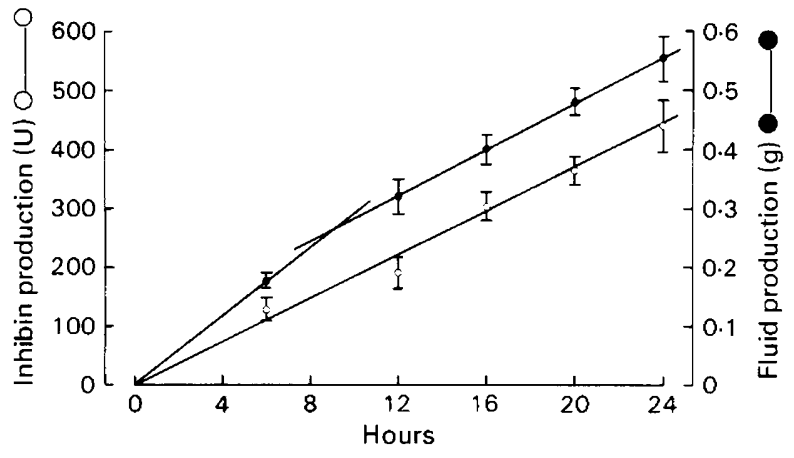

Text-fig. 1. The accumulation of inhibin and seminiferous tubule fluid with time after unilateral efferent duct ligation. Values are means \pm s.e.m. for 7 rats per group.

\section{Effects of bilateral cryptorchidism}

Using the efferent duct ligation technique, a significant reduction $(P<0.001)$ in the rate of production of inhibin and seminiferous tubule fluid was found 3 days after cryptorchidism, although the inhibin content in cryptorchid testes at this time was unchanged (Table 2). A significant decrease in testicular inhibin content was not observed until after 10 days when testis weight was then significantly lowered. The decline in inhibin production by 10 days after cryptorchidism was approximately 10 times greater than the corresponding decline in fluid production. Inhibin concentrations in interstitial fluid also significantly decreased after cryptorchidism and by 10 days were $<12 \mathrm{U} / \mathrm{ml}$ (compared to the value of $78.7 \pm 6.4 \mathrm{U} / \mathrm{ml}$ in control rats). After cryptorchidism, there was a significant increase $(P<0.001)$ in serum FSH levels by 10 days, and in LH values at 25 days.

Table 2. Changes in the weight, seminiferous tubule fluid production, inhibin content and inhibin production index of the testis and serum levels of gonadotrophins after bilateral cryptorchidism in adult rats

\begin{tabular}{|c|c|c|c|c|c|c|}
\hline & \multicolumn{2}{|c|}{ Day 3} & \multicolumn{2}{|c|}{ Day 10} & \multicolumn{2}{|c|}{ Day 25} \\
\hline & Control & Cryptorchid & Control & Cryptorchid & Control & Cryptorchid \\
\hline $\begin{array}{l}\text { Non-ligated testis wt (g) } \\
\text { Seminiferous tubule fluid }\end{array}$ & $1.64 \pm 0.07$ & $1.51 \pm 0.07$ & $1.69 \pm 0.06$ & $0.69 \pm 0.03^{*}$ & $1.76 \pm 0.05$ & $0.54 \pm 0.05^{*}$ \\
\hline $\begin{array}{l}\text { production }(\mathrm{g} / 16 \mathrm{~h}) \\
\text { Inhibin content (U) }\end{array}$ & $0.43 \pm 0.03$ & $0.27 \pm 0.03^{*}$ & $0.43 \pm 0.03$ & $0 \cdot 17 \pm 0.03^{*}$ & $0.46 \pm 0.03$ & $0.25 \pm 0.03^{*}$ \\
\hline $\begin{array}{l}\text { (non-ligated testis) } \\
\text { Inhibin production }\end{array}$ & $195 \pm 20$ & $238 \pm 18$ & $169 \pm 12$ & $37 \pm 3^{*}$ & $175 \pm 7$ & $18 \pm 2^{*}$ \\
\hline index $(\mathrm{U} / 16 \mathrm{~h})$ & $269 \pm 15$ & $168 \pm 22^{*}$ & $283 \pm 8$ & $13 \pm 4^{*}$ & $295 \pm 21$ & $1 \pm 1^{*}$ \\
\hline $\begin{array}{l}\text { Serum FSH }(\mathrm{ng} / \mathrm{ml}) \\
\text { Serum LH }(\mathrm{ng} / \mathrm{ml})\end{array}$ & $\begin{array}{c}313 \pm 21 \\
0.65 \pm 0.06\end{array}$ & $\begin{array}{c}251 \pm 27 \\
0.34 \pm 0 \cdot 10\end{array}$ & $\begin{array}{c}274 \pm 31 \\
0.59+0 \cdot 12\end{array}$ & $\begin{array}{c}500 \pm 42^{*} \\
1.68+0.53\end{array}$ & $\begin{array}{c}292 \pm 12 \\
0.77+0 \cdot 12\end{array}$ & $\begin{array}{c}564 \pm 45^{*} \\
1.93+0 \cdot 25^{*}\end{array}$ \\
\hline
\end{tabular}




\section{Discussion}

Our previous studies have used the measurement of the testicular inhibin content as an indicator of inhibin production and have shown an inverse correlation between this value and serum FSH concentrations (Au et al., 1983). The present study demonstrates that the inhibin content of the testis is represented by at least two components, (1) the amount of inhibin in the interstitial fluid or lymph and (2) the intratubular content. The inhibin activity in testicular interstitial fluid of $120 \pm 7$ $\mathrm{U} / \mathrm{ml}$ can be taken effectively as representing the concentration in testicular lymph. Setchell \& Sharpe (1981) have measured lymph flow in adult rat testes as $34 \pm 6 \mu 1 / \mathrm{g}$ testis weight/h (mean \pm s.e.m.) and when this rate is applied to the data from the present study, the estimated inhibin release rate via testicular lymph would be equivalent to $6.3 \mathrm{U} / \mathrm{h}$. Whether inhibin is also released into the testicular venous blood cannot be concluded from the present study. Unless methods for extraction or concentration of inhibin are used, its measurement in blood has to await the development of more sensitive assays.

The linear increase of inhibin in the testis during the first $24 \mathrm{~h}$ after efferent duct ligation over the 24-h period of study indicates that this technique can be used to obtain an index of inhibin release into the seminiferous tubule lumen. Additionally, raising the temperature of the ligated testes did not appear to affect the degradation of the accumulated inhibin over the 16-h period of the study. Furthermore, since the non-ligated testis did not exhibit a compensatory increase in inhibin content and the serum gonadotrophin levels did not show any significant variation, it can be assumed that no immediate gross disturbance of the feedback relationship between the pituitary and testis occurred.

Since Sertoli cells do not contain stored secretory granules that are typical of protein-secreting cells (Fawcett, 1975), it may be assumed that any inhibin produced is released rapidly. Consequently, the increase in the inhibin content of the testis after efferent duct ligation can be taken to represent inhibin secretion into the lumen of the seminiferous tubule and is unlikely to represent an accumulation in the intertubular compartment. The validity of this assumption can be tested from the arguments presented below.

The concentration of inhibin in seminiferous tubule fluid produced after efferent duct ligation $=$ inhibin accumulation/seminiferous tubule fluid production. Using the data in Table 1 , the inhibin activity in rat seminiferous tubule fluid can be calculated to be $756 \pm 39 \mathrm{U} / \mathrm{ml}$. Since the inhibin content of the unligated testis is $180 \pm 8 \mathrm{U} / \mathrm{ml}$, the volume of seminiferous tubule fluid is equivalent to $180 / 756 \mathrm{ml}(=0.24 \mathrm{ml})$. If these data are applied to testes with a mean weight of 1.54 $\pm 0.03 \mathrm{~g}$ and volume of $1.49 \mathrm{ml}$, taking the specific gravity of adult rat testes as 1.0354 (unpublished data), the volume percentage of the seminiferous tubule fluid is $0.24 / 1.49 \times 100 \%(16 \cdot 1 \%)$. This figure is in close agreement to that obtained by the morphometric measurements of the seminiferous tubule lumen of Johnson, Petty \& Neaves (1980) of $17 \cdot 3 \%$. This agreement supports the assumption that the release of inhibin in the $24 \mathrm{~h}$ after efferent duct ligation is predominantly into the seminiferous tubule fluid. It is possible, however, that the concentration of inhibin in interstitial fluid may change after efferent duct ligation and the associated rise in intratubule pressure, a factor which requires further exploration.

The results of the present study suggest that the accumulation of inhibin after efferent duct ligation is a more sensitive index of inhibin production than simple measurement of the inhibin content of the testis. This view is based on the study of cryptorchid rat testes in which a decrease in the inhibin production index occurs before a decline in the inhibin content of the ligated testes. Parallel changes occurred in seminiferous tubule fluid production which was also significantly lower 3 days after inducing cryptorchidism and has been taken as an indicator of impaired Sertoli cell function. The changes in ABP content and production also occur over a similar time course following cryptorchidism (Jégou, Risbridger \& de Kretser, 1983). Consequently, the content of the unligated testis and the short-term increment after unilateral efferent duct ligation for ABP, inhibin and seminiferous tubule fluid can all be considered as indicators of Sertoli cell function.

As observed in this study inhibin production parallels the changes in tubule fluid production 
after efferent duct ligation and the induction of cryptorchidism. Whilst there may be a relationship between the two sets of values, the decline in inhibin production by 10 days after induction of cryptorchidism is nearly 10 times greater than the corresponding decline in fluid production (Table 2). The magnitude of this difference would suggest that changes in inhibin production are not directly related to changes in fluid production but more to the overall dysfunction of the seminiferous tubule as a consequence of cryptorchidism. However, since the inhibin production index represents an amalgam of inhibin synthesis and secretion, and fluid production by the Sertoli cell, it is possible that under experimental conditions when the effects on inhibin secretion are at variance with fluid production, the results could be confusing. Furthermore, should experimental procedures result in a disruption of the blood-testis barrier, as expressed morphologically in the rat by the specialized inter-Sertoli cell junction, then there would be interference in the accumulation of fluid and inhibin after efferent duct ligation. In such situations leakage into the intertubular compartment may account for a decrease in seminiferous tubule fluid production and the inhibin production index. This is unlikely to be a problem after cryptorchidism since a number of studies have demonstrated structural integrity of the inter-Sertoli cell junctions (Hägenas, Ploen, Ritzén \& Ekwall, 1977; Kerr, Rich \& de Kretser, 1979; Aumuller, Hartmann, Giers \& Schenck, 1980).

This work was supported by a grant from the National Health and Medical Research Council of Australia. C.L.A. was supported by the British Commonwealth Scholarship and Fellowship Plan Award from the Australian Government. We thank Mrs S. Ellis, Mrs A. Davies and Mrs J. Trewin for technical assistance and the NIH for gonadotrophin radioimmunoassay kits.

\section{References}

Au, C.L., Robertson, D.M. \& de Kretser, D.M. (1983) In vitro bioassay of inhibin in testes of normal and cryptorchid rats. Endocrinology 112, 239-244.

Aumuller, G., Hartmann, K., Giers, V. \& Schenck, B. (1980) Fine structure of the Sertoli cells of the rat testis in experimental unilateral cryptorchidism. Int. J. Androl. 3, 301-311.

Baker, H.W.G., Bremner, W.J., Burger, H.G., de Kretser, D.M., Dulmanis, A., Eddie, L.W., Hudson, B., Keogh, E.J., Lee, V.W.K. \& Rennie, G.C. (1976) Testicular control of follicle stimulating hormone secretion. Recent Prog. Horm. Res. 32, 429-476.

Baker, H.W.G., Burger, H.G., de Kretser, D.M., Eddie, L.W., Higginson, R.E., Hudson, B. \& Lee, V.W.K. (1978) Studies on purification of inhibin from ovine testicular secretions using an in vitro bioassay. Int. $J$. Androl., Suppl. 2, 115-123.

Blanc, M.R. \& Dacheux, J.L. (1976) Existence of inhibin like activity in the ram rete testis fluid: Effect of physiological doses on plasma $\mathrm{LH}$ and FSH. IRCS Med. Sci. 4, 460.

de Kretser, D.M., Sharpe, R.M. \& Swanston, I.A. (1979) Alterations in steroidogenesis and human chorionic gonadotropin binding in the cryptorchid rat testis. Endocrinology 105, 135-138.

Duncan, D.B. (1955) Multiple range and multiple F tests. Biometrics 11, 1-42.

Eddie, L.W., Baker, H.W.G., Higginson, R.E. \& Hudson, B. (1979) A bioassay for inhibin using pituitary cell cultures. J. Endocr. 81, 49-60.

Fawcett, D.W. (1975) Ultrastructure and function of the Sertoli cell. In Handbook of Physiology, Section 7: Endocrinology, Vol. V. Male Reproductive System, pp. 21-55. Eds R. O. Greep \& D. W. Hamilton. American Physiological Society, Washington, D.C.

Finney, D.J. (1964) Statistical Method in Biological Assay, 2nd edn. Charles Griffin, London.

Hägenas, L. \& Ritzén, E.M. (1976) Impaired Sertoli cell function in experimental cryptorchidism in the rat. Molec. cell. Endocr. 4, 25-34.

Hägenas, L., Ploen, L., Ritzén, E.M. \& Ekwall, H. (1977) Blood testis barrier: Maintained function of interSertoli cell junctions in experimental cryptorchidism in the rat, as judged by a simple lanthanum-immersion technique. Andrologia 9, 250-254.

Jégou, B., Laws, A. \& de Kretser, D.M. (1982a) Effects of exposure of the rat testis to a single episode of heating: changes in the germ cells, Sertoli cells and Leydig cells. Proc. 14th A. Conf. Aust. Soc. Reprod. Biol. 4, Abstr. 52.

Jégou, B., Le Gac, F. \& de Kretser, D.M. (1982b) Seminiferous tubule fluid and interstitial fluid production. I. Effects of age and hormonal regulation in immature rats. Biol. Reprod. 27, 590-595.

Jégou, B., Risbridger, G.P. \& de Kretser, D.M. (1983) Effects of experimental cryptorchidism on testicular function in adult rats. J. Androl. 4, 88-94.

Johnson, L., Petty, C.S. \& Neaves, W.B. (1980) A comparative study of daily sperm production and testicular composition in humans and rats. Biol. Reprod. 22, 1233-1243.

Kerr, J.B., Rich, K.A. \& de Kretser, D.M. (1979) Effect of experimental cryptorchidism on the ultrastructure and function of the Sertoli cell and peritubular tissue of the rat testis. Biol. Reprod. 21, 823-838. 
Le Gac, F. \& de Kretser, D.M. (1982) Inhibin production by Sertoli cell cultures. Molec. cell. Endocr. 28, 487498.

Scott, R.S., Burger, H.G. \& Quigg, H. (1980) A simple and rapid in vitro bioassay for inhibin. Endocrinology 107, 1536-1541.

Setchell, B.P. \& Sharpe, R.M. (1981) Effect of injected human chorionic gonadotrophin on capillary permeability, extracellular fluid volume and the flow of lymph and blood in the testes of rats. J. Endocr. 91, 245-254.
Setchell, B.P. \& Sirinathsinghji, D.J. (1972) Antigonadotrophic activity in the rete testis fiuid, a possible "inhibin". J. Endocr. 53, x-xi, Abstr.

Smith, G. (1962) The effects of ligation of the vasa efferentia and vasectomy on testicular function in the adult rat. J. Endocr. 23, 385-399.

Steinberger, A. \& Steinberger, E. (1976) Secretion of an FSH-inhibiting factor by cultured Sertoli cells. Endocrinology 99, 918-921.

Received 7 October 1983 